\begin{tabular}{|c|c|}
\hline $\begin{array}{l}\text { EUROPEAN } \\
\text { PUBLIC \&OCIAL } \\
\text { INNOVATION } \\
\text { REVIEW }\end{array}$ & $\begin{array}{l}\text { European Public \& Social Innovation Review (EPSIR), Vol. } 2 \text { (2), 2017, ISSN 2529-9824 } \\
\text { Tuur Ghys } \\
\text { (C) Sinnergiak, Some Rights Reserved (cc) BY-NC-ND} \text { Creative Commons } 4.0 \text { International }\end{array}$ \\
\hline
\end{tabular}

\title{
ANALYSING SOCIAL INNOVATION THROUGH THE LENS OF POVERTY REDUCTION:
}

\author{
Five key factors
}

Tuur Ghys

Universidad Autónoma de Nuevo León

\begin{tabular}{l} 
KEY WORDS \\
\hline Social innovation \\
Poverty \\
Poverty reduction \\
Structural analysis \\
Research design
\end{tabular}

\section{Introduction}

Research on social innovation has picked up in Europe in the last decade, including numerous independent local investigations as well as bigger EU wide research projects (Jenson, Harrisson, 2013; Moulaert, Mehmood, MacCallum, Leubolt, 2017). As in many emerging fields the majority of the present research is (single) case study based, yet the number of comparative research, meta-analysis and larger $\mathrm{N}$ samples is growing. Yet as this field of social innovation research, the need emerges to embed the analysis of SI initiatives more strongly in relation to specific societal challenges or fields.

This article makes the case that as far as the subject of poverty reduction is concerned, social innovation (SI) researchers should take certain factors into account for designing their research when analysing the potential of SI to deal with this specific social problem. In what follows we will further discuss the need for such reflections, outline our understanding of poverty as a structural problem and finally present the foundations of an analytical framework based on five factors relevant to structural poverty reduction.
In the last decades social innovation has attracted much research attention, with a variety of projects studying how social needs are approached in innovative ways. However social they react to. This article develops an analytical framework to study social intovations relation to structural poverty reduction. After explaining the underlying theory on poverty, it described five key factors and twelve sub-factors to be taken into account for the design of research on social innovation in the field of poverty. This includes: the relation to the structural production of poverty; the relation to the position of people in poverty; the relation to solidarity and political conditions; the diffusion, scale and continuation and finally the relation to government and existing poverty programs. 


\section{Bridging the fields of social innovation and poverty reduction}

We shall broadly understand SI as societal reactions to social needs through the transformation of social relations, leading to new forms of organization, roles, ideas, etc. (Ghys \& Oosterlynck, 2013; Moulaert et al; 2013). Many of the initial research in the field was interested in the dynamic of the SI process itself. In order to consolidate the concept it was necessary to study and describe this particular form of innovation (see for example Mumford, 2002; Mumford, Moertl, 2003; Moulaert et al, 2005; Huddart, 2010). Besides developing an interest in the historical roots of both the concept (Godin, 2012) and the practices, this lead to the now relatively well known insights on the importance of bringing together different types of actors, leadership, etc. Much research in the field typically started and still starts from case studies, whether it is to document a specific innovation (for example Novy, Leubolt, 2005) or to compare multiple cases (Martinelli et al, 2003; Haddock, Tornagli, 2013). Some research projects today even aim to gather a thousand case studies ${ }^{1}$. Once this type of research gained popularity and policy attention, interest grew in upscaling and spreading SI practices (Davies, Simon, 2013, p. 6). A considerable amount of publications is concerned with the dynamic and growth of SI (Westley, Antadze, 2009; Simon et al, 2014; Davies, 2014), or at least with the challenges and pitfalls that can stand in the way of implementing social innovations.

This agenda however has important limitations for the (sociological) generation of knowledge concerning the content and role of SI within current society. When we do not a priori assume more SI is always 'good' (REFS), the question remains how these phenomena relate to social change and the needs they react to. Within the context of an isolated (historical) case study this could still be analysed in relation to one very specific need, but eventually as a field it is hard to capture the transformation of social relations without knowledge of the specific social problems. As Brandsen (2014) indicates there is a need for research on "the impact and outcomes of social innovation on urgent problems in contemporary society" (p. 14). Studying SI from the perspective of sustained, structural problems (climate change, poverty, etc.) can shed additional light on the deeper structural impact (or lack thereof) of SI processes: "For social innovation to be successful and have durability, the innovation should have a measurable impact on the broader social, political, and economic context that created the problem in the first place" (Cahill, 2010, p. 1; see also Fontan, 2016). Yet determining this success is hard without knowledge and criteria relating to the specific challenge.

Poverty reduction is an interesting avenue to pursue such research. Poverty is a key social problem facing our European societies and has been named a flagship issue for SI (BEPA, 2011). Although it can have specific local manifestations, it can be studied as a common problem within the capitalist world. And importantly it is not a new problem, with academic attention for its structural nature going back to the first sociologists like Marx and Simmel, allowing the contribution of SI to be investigated against a background of already known and tested policy responses.

Furthermore, the study of SI in relation to structural poverty reduction should also be of interest to social policy scholars. Various scholars have expressed the hope that SI can contribute to tackling existing social needs of vulnerable groups (Leubolt, Novy \& Beinstein, 2009; Avelino \& Wittmayer, 2014) and be a new paradigm for social policy (Sinclair, Baglioni, 2014). Yet the topic also connects to other longer standing concerns in the field of poverty and social policy. Amongst others Alcock (2005) is critical of the encouragement of community oriented initiatives, as was the case in the U.K. in the nineteen seventies and after the turn of the twenty first century, as he is skeptical of the potential of such initiatives to challenge structural problems. The resurging attention for SI seems to fit within recurrent strategies in social policy aiming at social cohesion and mutual exchange of support (Eizaguirre et al, 2012). In such cases there is a risk of turning SI into expectations of self-help or even a return to charity (Sinclair \& Baglioni, 2014; Ghys, 2016), without further investment of resources or 
structural changes (Eizaguirre et al., 2012, p. 2008).

Finally, studying innovative responses can help reflecting on poverty reduction itself, since it can help uncover new needs or deficiencies in current responses. Many of the recent E.U. Framework Program 7 research projects that pay explicit attention to poverty and SI, such as WILCO (Brandsen, 2014) and ImPRovE (Oosterlynck et al, 2013), focus on the latter and generate important reflections on the governance of poverty and SI. Yet they approach poverty/the welfare state from the perspective of SI, rather than SI from the perspective of structural poverty reduction. This paper aims to set out one possible analytical framework to do so, that has previously been utilized in (comparative) research (self reference; for an isolated case on social restaurants, see self reference).

\section{Poverty as a structural social problem}

We start by following Townsend (2010) in approaching poverty as a relative concept, a durable social phenomenon instead of some absolute condition of nigh starvation. Conceptualizations of poverty should combine a focus on the core context of material inequality with a broader understanding of multiple deprivations (Hick, 2012). We will thus define poverty as the condition in which person have such a shortage of economic resources in relation to the general distribution that they become socially excluded on multiple domains of life (Dierckx \& Ghys, 2013). This is possible in a commodified society (Polanyi, 1968) where money mediates most other goods, and a shortage in economic means will result in accumulated exclusion from other areas such as for example housing. Since poverty is related both to the general distribution of resources in society (inequality) and to how social forces react to this lack of resources (exclusion), poverty should be conceived as a structural societal problem (Royce, 2015; Vranken, 2001; Holman, 1978). The structural nature of the problem is further underscored by the fact that in most European welfare states there has been little substantial progress in reducing aggregate poverty in the last four decades (Cantillon, Collado \& Van Mechelen, 2015).

The structural nature of poverty can be perceived from two perspectives: that of the reproduction of poverty on a societal scale, and that of obstacles facing individuals in poverty (Ghys \& Oosterlynck, 2013, a similar distinction is made by Royce, 2015). The first refers to the fact that given a certain configuration of societal characteristics, $\mathrm{X} \%$ of the population is at risk of becoming poor. The second refers to the obstacles that people in poverty face in escaping poverty, which from their position appear as unalterable (but sometimes avoidable). In this section we shall mainly focus on the first meaning, since it largely encompasses the second.

What, then, are some of the structural mechanisms that produce poverty in capitalist welfare states? Although many scholars agree on separate causes, comprehensive structural explanations of poverty are rare (Jordan, 1996). We will give a necessarily brief, simplified and stylized overview of the main elements of the underlying theory on which the analytical framework for SI and poverty reduction is based (for more detail see self reference, or compare Royce, 2015).

When looking at the structural context within which poverty emerges, we must first note the existence of pervasive inequality. Without this relative poverty is impossible (Vranken, 2001), and inequality fuels most other structural causes such as exclusion or the accumulation of needed resources in the hands of few (Holman, 1978; Royce, 2015). We can also note the individualization of needs in society as another 'meta' condition, which entails that individuals (increasingly) need to partake in a largely privatized economic process in competition with all others to satisfy their needs (Ghys, 2014). This means that those who struggle to make an independent income (for example the sick or children) become vulnerable as there is no strong natural collective to fall back on (Simmel, 1908; Jordan, 1996). 
There is thus a structural generation of vulnerability in society.

Next we can look at where poverty is actually produced, starting with the labor market, where two mechanisms stand out. The first is exploitation, by which we shall not just understand instances of modern slavery (Bales, 2007), but in a broad Marxist sense being paid insufficiently in relation to the generated profit or value (Jordan, 1996). Within the context of Western Europe this was for long not seen as an important cause, yet in the last decade worries about the 'working poor' have reentered the debate (Marx, Vanhille \& Verbist, 2010; Standing, 2011). Secondly, and within the European context often more significant, is the production of poverty through the existence of (structural) unemployment. This refers to the fact that at any given time the capitalist labor market is most likely to find equilibrium below full employment, resulting in the existence of less jobs than workers (Harvey, 1999; Royce, 2015). This is further driven by the replacement of people by machines in the classic (yet very timely) Marxist conception, but also through processes of globalization causing shifts in the demanded competencies and endangering low educated people in sectors that move overseas (Elchardus \& Pelleriaux, 2001; Royce, 2015). In addition, even in good times there will be constant personal crises in income due to friction unemployment and changes in demand, seasonal labor and after companies close due to creative destruction (Schumpeter, 1976). Somewhere in between exploitation and unemployment we must also note the many temporarily, uncertainly or part time employed (Marx, Vanhille \& Verbist, 2010), who face a hard path towards gathering sufficient income and building social rights over time. The problem in many of these elements is not so much the unemployment in itself, but the crises in income (and morale) that they structurally generate.

Another important mechanism in the production of poverty is social exclusion. Since social exclusion can threaten to become a catch all concept, we will understand it by distinguishing between two specific processes: active and passive social exclusion (Ghys, 2014). First comes 'active' social exclusion, by which we shall refer the intentional exclusion of people based on certain characteristics. This can vary across societies, as some characteristics (ethnic background, sex, etc.) might result in reduced access to key markets (labor, housing, credit, etc.) while others (hair color) don't. More complicated is passive social exclusion, which relates to the structural commodification of goods under capitalism (Polanyi, 1968), which means that they can only be obtained through exchange on the marketplace. As Robinson explains:

"Capitalism expands by commodifying social relations, the process whereby capitalist production, or commodity production, replaces pre- or noncapitalist forms of production. (...) commodification constantly deepens; human activities that previously were outside the logic of capitalist production are brought into this logic" $(2004$, p. 6).

The practical consequence of this is that people with few economic resources structurally run the risk of becoming excluded from key social goods such as transport, housing, education, health, etc. We call this exclusion 'passive' because in a competitive market sellers normally don't intentionally exclude customers from buying things (unless they sell exclusivity). Yet it means that those who have little accumulate disadvantages, affecting both those experiencing a crisis in income, as well as those born in poverty ('generational poor') or making a humble entrance to society (refugees, etc.).

Thus far we described the structural production of vulnerability, income crisis and social exclusion within a context of inequality. The welfare state usually has mechanisms to compensate the emerging shortage of economic means through various social security and social assistance systems (Garland, 2014). Although the topic has a technical depth that cannot be discussed here, we must also pay attention to the apparent failure of these systems to prevent the production of poverty for a significant part of the population (Cantillon et al, 2015). Besides certain administrative holes or exclusions in access to the net (for example homeless people lacking registry), we often see that it simply 'hangs too 
low' and compensates below the poverty line. This can be due to external pressure and/or lack of budget, as recently happened in Greece, but often social security and especially assistance rates are historically intended to be below the poverty line (Vranken, 1977). When social security and assistance structurally falls short, large groups of people (elderly, people with handicaps, etc.) are left in poverty.

The previous observations give insight in the production of poverty, yet when we realize that this problem has endured for decades without significant reductions, we must also pay attention to the structural reproduction or acceptance of poverty. The full question is not just why there is poverty, but why there exists poverty while we know it exists: "poverty is not eliminated even when society has sufficient affluence to achieve this end, for it exists for reasons other than a total lack of resources" (Holman, 1976, p. 202; Green, Hulme, 2005). As Royce (2015) argues, a complete understanding of the reproduction includes paying attention to cultural and political structures.

To start with we must understand that the social change and redistribution required to undo some of the structural causes of poverty often runs against the interests of certain powerful groups in society (Dierckx, Ghys, 2013). At the same time, certain authors think that the existence poverty itself is functional to certain groups (Gans, 1996). We must thus pay attention to the political and cultural discourses that discourage or distract from structural solutions (Hirschman, 1991; Somers, Block, 2005), as well as those that stigmatize the poor, making them 'underserving' of help or solidarity (Gans, 1996; Taylor-Gooby, 2013). And finally as Royce (2015) reminds us we must take inequality in terms of political power into account, given the poor often to don't have the (economic, cultural, etc.) resources to effectively defend their interests.

In such conditions, what would structural poverty reduction conceptually entail? When we see poverty as a durable structural problem, a serious understanding of structural poverty reduction entails those actions that address structural causes and in doing so contribute to the aggregate reduction of poverty in the long term. In what follows we will relate various elements of this structural understanding of poverty as a societal challenge to the potential of (local) social innovation initiatives to contribute (or not) to such a cause.

\section{Five factors of analysis}

In this part we will develop the foundations of an analytical framework that can be used to investigate social innovations through the lens of structural poverty reduction. Since we consider the positive/negative impact of SI an empirical (rather than conceptual) question, this framework takes into account both potential contributions and problems/pitfalls for the relation to poverty reduction. The analytical framework consists of five main factors that deserve study in any analysis of the relation between SI and poverty, which are further split up into 12 sub-factors (see table 1). The further optimization of this analytical into to actual points of attention, methods of data collection, coding lists, etc., depends on the particular research project and goals. This article will merely suggest some more detailed points of attention that seemed promising to include in research design, based on the literature and the use of the earlier framework in case studies. The order of the factors and sub-factors is random, and the splitting up of the deeply connected issue of poverty reduction into factors is purely for analytical purposes. 
Table 1. Overview analytical framework structural poverty reduction

\begin{tabular}{|c|c|}
\hline Factor & Subfactor \\
\hline \multirow[b]{2}{*}{ 1. Relation to structural production of poverty } & Focus on structural causes \\
\hline & $\begin{array}{l}\text { Introduction of new institutions / collective } \\
\text { services }\end{array}$ \\
\hline \multirow{3}{*}{ 2. Relation to position of people in poverty } & Reaction to social needs of individuals \\
\hline & Access and outreach of SI initiative \\
\hline & Power relations within the SI initiative \\
\hline \multirow{3}{*}{ 3. Relation to solidarity and political conditions } & Politicization of social needs \\
\hline & Awareness raising on poverty \\
\hline & Mobilization of people in poverty \\
\hline \multirow{2}{*}{ 4. Diffusion, scale and continuation } & Spread and weight of the SI \\
\hline & Conditions for continuation and future growth \\
\hline \multirow{2}{*}{ 5. Relation to government and poverty programs } & $\begin{array}{l}\text { Role of government and contact with welfare } \\
\text { services }\end{array}$ \\
\hline & Tensions in task division and responsibility \\
\hline
\end{tabular}

Source: Own elaboration

a. Relation to the structural production (causes) of poverty

The first factor directly follows from the theoretical discussion on the structural production of poverty, and relates to the degree in which a SI is aimed at changing to socio-economical structures that are essential to the structural production of poverty. The critical question is how the SI relates to causes like unemployment, low wages or replacement incomes, commodification, inequality, etc. This factor is different from the third (relation to subjective conditions) in so far that it focuses on social and economic, rather than cultural and political causes. It differs from the second factor (relation to position of people in poverty) in that it focuses on societal mechanisms that are external to the life/power of individuals in poverty, yet that determine the overall chance of poverty for everyone in society. In other words the focus is systemic and institutional, not (inter)personal (compare Royce, 2015). For example in the case of 'active exclusion' related to racism, the focus would not be on empowering the individual, but on the legislation and institutional racism.

We can split this up into two sub-factors that to a certain extend can be investigated separately. The first sub-factor is concerned with the approach and focus of the initiative: to what degree is the SI aimed at structural causes of poverty (as opposed to other approaches)? Certain things, such as giving food packages, are simply not aimed at causes of poverty (Self Reference). Others, such as workshops on family values or saving, don't start from a structural analysis. Points of attention are thus the goals of innovators, their analysis of the poverty problem, and in what degree those tend towards a structural or individualizing view (Holman, 1978; Royce, 2015).

The second sub-factor proposes to study how the SI could contribute to systemic change by introducing new institutions or collective services. Attention should be paid to if the SI argues for different principles, or institutions that are alternative to the normal principles in society and the market (Sinclair, Baglioni, 2014). Examples of this include various social economy initiatives, from social employment (f.e. self reference) to cooperatives (Ranis, 2016). Historical examples include trade unions or social insurance. Special attention should be paid to SI that has potential for collective services, both because these can have a de-commodifying effect (Esping-Andersen, 1990; Royce, 2015), and because they can also impact the production of poverty of the not-yet-poor (Vranken, 2014, p. 51). This factor might seem to place the bar high for SI, because most are localized initiatives that 
emerge in relation to a context specific unmet need. However: a) that should not change our analysis, b) we must also pay attention to the alternative logics that innovations carry, regardless if it in itself succeed in realizing this.

\section{b. Relation to the position of people in poverty}

The second factor focuses on the relation between the SI and the excluded position of concrete individuals in poverty. Is the approach of the SI aimed at improving the situation of individuals in poverty, does it counter (or consolidate) certain exclusions or obstacles in the trajectory out of poverty? Whether something is a structural obstacle (f.e. a staircase) for an individual depends on their position in society, it can be an obstacle for some but not for others. Ideally a SI can either eliminate a specific type of exclusion, or empower the individual in a way that shortens the duration in poverty. Yet attention should also be paid to the position of people in poverty within innovative initiatives.

The first sub-factor relates to the question of if and how the SI reacts to the social needs (material or otherwise) of individuals in poverty, and if this tackles exclusions or generates opportunities. Points of attention are how significant the contribution to material needs is, if the SI generates opportunities for social mobility and what the logic behind this is, and what resources are allocated to these goals. It can be challenging to study the extent to which a certain activity has potential to poverty reduction. It is not uncommon for social innovators and policy makers to project the goal of social mobility on a (questionably) wide range of activities (Ghys, 2016; Alcock, 2005). The challenge for the individual researcher is to calibrate her analytical criteria to make a meaningful distinction between the relative value of watering plants and debt resettlement. We suggest taking into account elements such as the directness with which something contributes to social mobility, the thoroughness with which these elements are integrated into the project, and if people in poverty actually receive levers to satisfy needs.

The second sub-factor investigates the relation to the position of people in poverty in terms of the access to the SI itself: what audiences is a SI willing and able to reach, and what potential barriers exist? Social innovation does not inherently contribute to social inclusion (Martinelli, 2012), or can favor certain groups above or at the cost of others. Points of attention are if the approach of the SI takes into account material barriers (for example ICT or transport), or the accessibility is limited for others groups (sex, religion, professional activity). Particular attention should be paid to stigma as a barrier.

The third sub-factor is concerned with the internal (power) relations within the SI itself. It is well known that SI transforms social relations, yet there is no reason to assume this will automatically favor people in poverty (refs). Power relations matter, in the example of a factory for the unemployed they make the difference between a cooperative and the $19^{\text {th }}$ century 'poor house' that created value for shareholders (Polanyi, 1968, p. 107). The research of Fairbanks II (2009) on unofficial alcohol rehabilitation houses shows how dealing with vulnerable people can also open risks of exploitation. A point of attention is thus the degree and nature of participation (which could contribute to social mobility), but also the potential of exploitation. The position of poor people should also be studied in relation to their dignity, especially if the SI is of charitable nature shame and stigma form important points of attention.

\section{c. The relation to solidarity and the political conditions for poverty reduction}

The third factor relates to the cultural and political mechanisms of the reproduction of poverty mentioned earlier in the theory. Here the focus is not on the 'objective' material conditions of poverty reduction (is it technically possible?), but on the subjective conditions, or the support, will and political climate to actually change things: "We have the know how, but we lack the political will and the political means necessary to put that knowledge into effect" (Royce, 2015, p. 254). 
It is easy to overlook this factor in studying SI, since it does not directly contribute to poverty reduction.

Yet changing it is key, since the fate of people in poverty largely depends on the political will to social change (Holman, 1978). However it is also possible that SI contributes to the 'undeservingness' (Gans, 1995) and stigmatization of the poor, consolidating their position at the bottom of society. We will split this factor into three sub-factors.

The first sub-factor is the degree in which a SI politicizes needs, thereby potentially challenging the acceptance of poverty. Not all SI aim to place the needs they react to on the political agenda or make an explicit case for structural poverty reduction. Attention should be paid to various types of politicization, ranging from making the initiative itself a form of protest (such as squatting collectives, see Pruijt, 2003), to initiating new civil society alliances and political networks. Another form of agenda setting is using the SI experiences to signal needs to policy. For example Dierckx, Vranken and Kerstens (2009) show how religious bottom up initiatives played an important role in Europe in signaling certain poverty trends to policy.

The second sub-factor is if sensitizing and awareness raising is part of the SI approach. This includes the explicit attempt to influence democratic majorities, who a) shape the policy; b) in their acts produce solidarity/exclusion. A shift in attitudes helps to both create better functioning welfare settlements, and to accept their correct use (Horton and Gregory, 2010; Lepianka, Oorschot \& Gelissen, 2009). Points of attention are the knowledge and position of the initiatives itself towards poverty and the poor (including stereotypes), but also if and how the SI uses media to spread their message to the wider public. Furthermore it is useful to investigate if the SI engages in external awareness raising, as well as the role that (fighting) stigmatization and stereotypes play within the initiative.

The third sub-factor raises the question to which degree the innovative transformation of social relations mobilizes of people in poverty around seeking solutions to their needs (Oosterlynck et al, 2013). Throughout time various authors have highlighted the importance of developing the political voice of people in poverty (Holman, 1978; Piven \& Cloward, 1979; Royce, 2015). Possible points of attention are the extent to which the SI actively stimulates reflection on collective needs of people in poverty (meetings, etc.), and if it mobilizes around a collective solution to problems. In case initiative is in direct dialogue with policy, the question becomes if and how they involve people in poverty in the governance.

d. The diffusion, scale and continuation of social innovation

Locale experiments can be interesting, yet a serious analysis of the contribution of SI to structural poverty reduction must take the factor diffusion and scale into account. Despite the strong interest in upscaling discussed in part one, many authors stress the local and context bound nature of SI (Chambon, David \& Devevey, 1982; Oosterlynck \& Cools, 2012; Brandsen, 2014). It is also true that growing SI doesn't necessarily lead to improvement, since it also enlarges potential problems and unforeseen consequences (Davies \& Simon, 2013). Yet while not inherently good, we believe that scale/weight is an important factor of analysis. When we take the structural nature of poverty serious, we have to concede that solutions need to carry a certain weight to impact the deep rooted mechanisms that sustain social problems. Diffusion and upscaling help to reach a broader audience, and is required to counter territorial inequality and exclusion in terms of welfare services (Andreottie, Mingione, Polizzi, 2012; Martinelli, 2012).

The first sub-factor looks at the growth and weight of the SI. As Davies and Simon advise (2013), SI research would benefit from making a distinction between the upscaling (organizational growth) and the dissemination (diffusing the model without changing the organizational scale) of 
innovations, which both can contribute to a larger weight. One point of attention researchers might want to take into account is the role of coordination amongst the involved actors in both processes. But also the concept of the SI itself matters, as certain innovations require a certain scale (collective health insurance) to operate, while others are context specific and face challenges in diffusion. Attention

should also be paid to what possibilities (and challenges) upscaling could bring for certain already mentioned aspects poverty reduction (politicizing, internal employment, etc.).

The second sub-factor deals with the conditions for further growth and sustainable continuation of the SI. Debate is possible on the need for SI to work long term, but in the context of a relatively durable structural problem as poverty it is at least interesting to factor the continuation of alternative institutions into the analysis. Attention should be paid to how the innovators see the future and which ambitions and worries they have for furthering their SI. As Brandsen (2014, p.9) mentions, the continuation of SI is vulnerable to changes in funding, dependence on certain leaders and political changes, etc. One could also look at the political support required for the initiative, and to what extend it is part of certain other social trends (Mumford, Moertl, 2003).

\section{e. The relation to the government and existing poverty programs}

The fifth factor deals with the degree to which government interference plays a role in the approach of a SI, and how this innovation relates to the wider institutional context of poverty reduction and social services. SI do not emerge in an institutional vacuum, but usually 'bumps' into elements of the (welfare) state early on, an interaction that already has been the subject of fruitful research (Oosterlynck et al, 2013). On the one hand, the legal framework, the type of available support, collaboration and the task division with the government all influence the approach of initiatives. On the other hand, SI could emerge as a reaction against the (mal) functioning of certain welfare services. Investigating this factor is important because it helps detecting potential fields of tension, and because the (lack of) structural contribution to poverty reduction cannot be assessed in isolation from the already existing and established landscape of social protection. We propose to group this in two subfactors.

We suggest mapping the practical role of governments on multiple levels in the approach and implementation of SI in the first sub-factor. Attention should be paid to the various contacts and SI has with existing (public or publicly financed) welfare services, and what role each actor plays within this relation. Institutional leaning processes are also a topic of interest if they can contribute to a more effective handling of poverty, especially if the SI coins certain ideas for improving services that it itself it unable to realize. Finally, we suggest reflecting on what elements of the poverty approach imply government assistance or can be realized at a fuller potential in collaboration with the state (for example through social employment subsidies).

The second sub-factor is concerned with the possible fields of tension in the division of tasks and responsibilities with the welfare state. One of those tensions emerges when government actors hinder the innovative potential of SI or overload it with pressure. This could for example happen when policy makers impose certain goals that deviate from the original intention (this could of course also be an improvement, which is an empirical question). One example of bad chemistry could be when a small homeless project is overwhelmed by new clients send by social services, or when unreasonably high activation targets are set for a labor market integration initiative working with the most difficult groups.

A second field of tension resolves around responsibility and the relation to existing public services. Various authors pointed out that, especially in times of austerity, the risk emerges that governments offload responsibilities onto SI initiatives (Moulaert et al, 2005; Oosterlynck, Cools, 2012). Regardless of the question if these shifts in responsibility are feasible, the responsiblity becomes 
less clear in the collaboration of public and other sectors (Bergmark, Minas, 2010). From the perspective of poverty reduction this shift can be especially problematic and thus worthy of research if it coincides with the erosion of existing (well functioning) welfare provisions or social rights (Martinelli et al, 2003; Mingione, 2014; Sinclair, Baglioni, 2014). A good example is the tension around shifting burdens between foodbanks and local social services (Lambie-Mumford, 2013; Tarasuk, Dachner, Loopstra, 2014).

\section{Conclusion}

The relation between social innovation and poverty is ambiguous, and not every initiative dealing with poverty has to potential to contribute to structural poverty reduction. This paper argued for a stronger grounding of research on the role of social innovations in an understanding of the social problems they pretend to react to. Consequentially, each field (sustainability, poverty, crime, etc.) should come with its own set of challenges, fields of tension, and points of attention. We outlined one possible analytical framework to do so for structural poverty reduction, by bringing theory and insights from the fields of poverty and SI together. This resulted in the above five factors relevant to structural poverty reduction that could be taken into account in the design of research and evaluation instruments. One merit of this approach is that is does not just points towards a more theoretically grounded analysis of the potential contribution, but also draws attention to more questionable aspects of SI in the field of poverty, such as offloading responsibility or stigmatization.

The analytical framework described in this paper was previously applied in research on the potential of social innovation in Belgium (self reference; for an example of a case study in English, see self reference). However in this article we just sketched the general outline of such a framework. If reproduced, this will have to be adjusted to fit other research projects, which in practice come with particular contexts and research questions. This includes matching it with methods for data collection. Methods like positioned interviews, document study, surveys of involved organizations (useful in early stages to get a sense of the variety in the field) and focus groups are common suspects in many SI research projects. Although the methodological operationalization of this framework goes beyond the scope of this paper, we want to add two particular suggestions. One is to consider an analysis of national (written) media on the social innovation in question, which can shed further light on the third factor of the relation to the political conditions of poverty reduction. The second suggestion is to interview or survey people in poverty themselves, especially for the second factor on the relation to the position of people of poverty. A serious representation of the perspective of people in poverty as clients or participants is often curiously missing in many case studies on SI; presumably for practical reasons in bigger research projects dealing with multiple cases. Still, we believe paying attention to these and other factors of poverty reduction are elementary to furthering our critical understanding of the contribution of social innovation. Otherwise we risk ending up writing about a paradoxical situation in which everybody seems to be involved in fighting poverty, but nobody reduces it.

\section{References}

Alcock, P. (2005). 'Maximum Feasible Understanding' - Lessons from Previous Wars on Poverty. Social Policy and Society, 4(3), 321-329.

Andreotti, A., Mingione, E., Polizzi, E. (2012). Local Welfare Systems: A Challenge for Social Cohesion. Urban Studies 49(9), 1925-1940.

Avelino, F., Wittmayer, J. (eds). (2014) Game-changers \& Transformative Social Innovation. Working paper, policy insights, lessons for facilitation tools and workshop report. TRANSIT Deliverable 
Bales, K. (2007). Ending Slavery: How we Free Today's Slaves. University of California Press.

Bergmark, A., Minas, R. (2010). Actors and Governance Arrangements in the Field of Social Assistance. In: Y. Kazepov, (Ed.). (2010). Rescaling Social Policies: Towards Multilevel Governance in Europe. Ashgate.

Brandsen, T. (2014). Wilco Final Report. Retrieved online: http://www.wilcoproject.eu Bureau of European Policy Advisers (2011). Empowering people, driving change: Social Innovation in the European Union. Retrieved online: http://ec.europa.eu/DocsRoom/documents/13402/

Cahill, G. (2010). Primer on social innovation: a compendium of definitions developed by organizations around the world. The Philanthropist, 23(3), 259-271.

Cantillon, B., Collado, D., Van Mechelen, N. (2015). The end of decent social protection for the poor? The dynamics of low wages, minimum income packages and median household incomes. Herman Deleeck Centre for Social Policy, University of Antwerp.

Chambon, J.-L., David, A., Devevey, J.-M. (1982). Les innovations sociales. Paris, Presses Universitaires de France.

Davies, A., Simon, J. (2013). Growing social innovation: a literature review. A deliverable of the project: "The theoretical, empirical and policy foundations for building social innovation in Europe" (TEPSIE). Brussels: European Commission, DG Research

Davies, A. (2014). Spreading Social Innovations: A Case Study Report. A deliverable of the project: "The theoretical, empirical and policy foundations for building social innovation in Europe" (TEPSIE). Brussels: European Commission, DG Research

Dierckx, D., Ghys, T. (2013). Solidariteit en herverdeling in structurele armoedebestrijding. In: D. Dierckx, J. Coene, A. van Haarlem, P. Raeymaeckers. (Eds.). Armoede en sociale uitsluiting Jaarboek 2013. Leuven/Den Haag: Acco.

Dierckx, D., Vranken, J., Kerstens, W. (Eds.). (2009). Faith-based organizations and social exclusion in European cities. Leuven: Acco.

Eizaguirre, S., Pradel, M., Terrones, A., Martinez-Celorrio, X., Garcia, M. (2012). Multilevel Governance and Social Cohesion: Bringing Back Conflict in Citizenship Practices. Urban Studies, 49(9), 1999-2016.

Elchardus, M. \& Pelleriaux, K. (2001). De nieuwe sociale kwestie: begripsverduidelijking en discussienota. TOR 2001(1).

Esping-Andersen, C. (1990). The three worlds of welfare capitalism. Cambridge: Polity Press. Fairbanks II, R. (2009). How it works. Recovering Citizens in Post-Welfare Philadelphia. Chicago: The University of Chicago Press.

Fontan, J.M. (2016). Social Innovation and Transformation: Coaching and Describing Societal Extension Through Research Partnerships. Paper for ImPRovE conference, February 2016.

Gans, H. (1996). The war against the poor. New York: Basic Books.

Garland, D. (2014). The Welfare State: A Fundamental Dimension of Mode Government. European Journal of Sociology, 55(3), 327-364.

Ghys, T. (2014). Naar een structurele theorie van armoede. In: G., Verschraegen, C. de Olde, S. Oosterlynck, F. Vandermoere, D. Dierckx (Eds.). (2014). Over gevestigden en buitenstaanders: Armoede, diversiteit en stedelijkheid. Leuven: ACCO.

Ghys, T. (2016). Sociale Innovatie en Structurele Armoedebestrijding. Antwerpen: OASeS.

Ghys,T.,Oosterlynck,S.(2013).Governance uitdagingen voor sociale innovatie en armoedebestrijding.

VLAS-Studies 8, Antwerpen: Vlaams Armoedesteunpunt. 
Godin, B. (2012). Social innovation: utopias of innovation from c.1830 to the present, Working Paper 11. Project on the Intellectual History of Innovation, Montréal: INRS. Retrieved online: http://www.csiic.ca/PDF/SocialInnovation_2012.pdf

Haddock, S.V., Tornaghi, C. (2013). A transversal reading of social innovation in European Cities. In: F. Moulaert, D. MacCallum, A. Mehmood, A. Hamdouch, (eds.). The international handbook of social innovation. Collective action, social learning and transdisciplinary research. Edward Elgar.

Harvey, D. (1999). The limits of capital (2nd ed). Verso.

Hick, R. (2012). The Capability Approach: Insights for a New Poverty Focus. Journal of Social Policy, 41(2), 291-308.

Hirschman, A. (1991). The Rhetoric of Reaction: Perversity, Futility, Jeopardy. Cambridge, MA: Harvard University Press.

Holman, R. (1978). Poverty. Explanations of Social Deprivation. London: Martin Robertson.

Horton, T., Gregory, J. (2010). Why solidarity matters: the political strategy of welfare design. The Political Quarterly, 81(2), 270-276.

Huddart, S. (2010). Patterns, principles, and principles in social innovation. The Philantropist, 23(3), 221-234.

Jenson, J., Harrisson, D. (2013). Social innovation research in the European Union. Approaches, findings and future directions. Policy review. European Commission. Retrieved online: http://www.net4society.eu/_media/social innovation.pdf

Jordan, B. (1996). A theory of poverty and social exclusion. Cambridge: Polity Press.

Lambie-Mumford, H. (2013). 'Every Town Should Have One': Emergency Food Banking in the UK. Journal of Social Policy, 42, 73-89.

Lepianka, D., Oorschot, W., Gelissen, J. (2009). Popular Explanations of Poverty: A Critical Discussion of Empirical Research. Journal of Social Policy, 38(3), 421-438.

Leubolt, B., Novy, A., Beinstein, B. (Eds.) (2009). Governance and Democracy - Katarsis survey paper.Retrieved online: http://www.academia.edu/214469/Governance and Democracy KATARSIS Survey Paper

Martinelli, F. (2012). Social Innovation or Social Exclusion? Innovating Social Services in the Context of a Retrenching Welfare State. In: H.W. Franz, J. Hochgerner, J. Howaldt (Eds.), (2012). Challenge Social Innovation. New York: Springer.

Martinelli, F., Moulaert, F., Swyngedouw, E., Ailenei, A. (2003). Scientific period progress report month 18. SINGOCOM.

Marx, I., Vanhille, J., \& Verbist, G. (2010). Werkend en toch arm in de actieve welvaartsstaat. In: J. Vranken, S. De Blust, D. Dierckx, A. Van Haarlem, A. (Eds.). Armoede en sociale uitsluiting Jaarboek 2010. Leuven: Acco.

Mingione, E. (2014). The contemporary dynamics of Capitalism and the tensions of the crisis interpreted within a theoretical frame centred on the double movement. International Karl Polanyi Conference, 6-8 November 2014.

Moulaert, F., Martinelli, F., Swyngedouw, E., González, S. (2005), Towards Alternative Model(s) of Local Innovation. Urban Studies, 42(11), 1969-1990.

Moulaert, F., MacCallum, D., Mehmood, A., Hamdouch, A. (2013). The international handbook of social innovation. Collective action, social learning and transdisciplinary research. Edward Elgar. 
Moulaert, F., Mehmood, A., MacCallum, D., Leubolt, B. (2017). Social Innovation as a Trigger for Transformations-The Role of Research. European Commission. Retrieved online http://ec.europa.eu/research/socialsciences/pdf/policy reviews/social_innovation trigger for transformations.pdf

Mumford, M. (2002). Social Innovation: Ten Cases From Benjamin Franklin. Creativity Research Journal, 14(2), 253-266.

Mumford, M., Moertl, P. (2003). Lessons from two innovations in the 20th century. Creativity Research Journal, 15, 261-266.

Novy, A., Leubolt, B. (2005). Participatory Budgeting in Porto Alegre: Social Innovation and the Dialectical Relationship of State and Civil Society. Urban Studies, 42(11), 2023-2036.

Oosterlynck, S., Y. Kazepov, A. Novy, P. Cools, E. Barberis, F. Wukovitsch, T. Sarius \& B. Leubolt (2013). The butterfly and the elephant: local social innovation, the welfare state and new poverty dynamics. ImPRovE Discussion Paper No. 13/03. Antwerp: Herman Deleeck Centre for Social Policy.

Oosterlynck, S., Cools, P. (2012). Lokale initiatieven als bouwstenen voor sociale innovatie. In: D. Dierckx, S. Oosterlynck, J. Coene, A. Haarlem. (Eds.). (2012). Armoede en Sociale uitsluiting Jaarboek 2012. Leuven: Acco.

Piven, F., Cloward, R. (1979). Poor People's Movements. Why they succeed, how they fail. New York: Random House.

Polanyi, K. (1944/1968). The Great Transformation. The political and economic origins of our time. Boston: Beacon Press.

Pruijt, H. (2003). Is the institutionalization of urban movements inevitable? A comparison of the opportunities for sustained squatting in New York City and Amsterdam. International Journal of Urban and Regional Research 27(1), 133-157.

Ranis, P. (2016). Cooperatives Confront Capitalism. Challenging the Neo-Liberal Economy. ZED books.

Robinson, W. (2004). A theory of global capitalism. London: The Johns Hopkins University Press

Royce, E. (2015). Poverty and power. The problem of structural inequality. Rowman \& Littlefield.

Schumpeter, J. (1976). Capitalism, Socialism and Democracy. Routledge.

Somers, R., Block, F. (2005). From Poverty to Perversity: Ideas, Markets, and Institutions over 200

Years of Welfare Debate. American Sociological Review 70(2), 260-287.

Simmel, G. (1908/1965). The Poor. Social Problems, 3(2). 118-140.

Simon, J., Schon, R., Kitcher, H., Millard, J., Carpenter, G., Ingermann, A. (2014). Growing the field of social innovation in Europe. A deliverable of the project TEPSIE. Brussels: European Commission, DG Research.

Sinclair, S., Baglioni, S. (2014). Social Innovation and Social Policy. Promises and Risks. Social Policy \& Society, 13(3), 469-476.

Standing, G. (2011). The Precariat. The New Dangerous Class. London: Bloomsbury.

Tarasuk, V., Dachner, N., Loopstra, R. (2014). Food banks, welfare, and food insecurity in Canada. British Food Journal 116 (9), 1405-1417.

Taylor-Gooby, P. (2013). Why do people stigmatise the poor at a time of rapidly increasing inequality, and what can be done about it? Political Quarterly, 84(1), 31-42.

Townsend, P. (2010). The meaning of poverty. The British Journal of Sociology, 61. Issue supplement s1. 
Vranken, J. (1977). Armoede in de welvaartsstaat: een poging tot historische en structurele plaatsing. Antwerpen: Universiteit Instelling Antwerpen.

- (2001). Unraveling the social strands of poverty: differentiation, fragmentation, inequality, and exclusion. In: H.T. Andersen, H.T, R. Van Kempen. (Eds.). Governing European Cities.

Aldershot: Ashgate.

- (2014). Thatcher aan de Schelde. Antwerpen: EPO.

Westley, F. \& Antadze, N. (2009). Making a difference. Strategies for scaling social innovation for greater impact. 